\title{
Praca człowieka i godne jej wynagradzanie w świetle encykliki Centesimus annus
}

\section{Wstęp}

Praca jest jedną z podstawowych aktywności człowieka. Podejmuje on celowe działania zmierzające ku przekształceniu dóbr przyrody i przystosowaniu ich do zaspokojenia potrzeb ludzkich po to, aby wzbogacać w szeroko rozumianym tego słowa znaczeniu - siebie i innych ludzi. Praca człowieka żyjącego w społeczeństwie oprócz indywidualnych korzyści mu przynoszących pozwala na utrzymanie kontaktu ze społeczeństwem przez wykonywanie czynności pożytecznych dla rozwoju wspólnoty. Praca ludzka ma wielowymiarowy charakter. Można na nią spojrzeć od strony filozoficznej, psychologicznej, fizjologicznej, ekonomicznej, pedagogicznej oraz społecznej.

Praca jest wartością, z której wypływają inne wartości, jest ona również potrzebą człowieka i warunkiem jego rozwoju. Stanowi podstawowe źródło utrzymania człowieka i warunkuje rozwój społeczno-gospodarczy danego kraju. Jest ona jednym z najlepszych sposobów wychowania, kiedy to człowiek, wykonując pracę, nieustannie rozwija się i kształtuje swój stosunek do pracy, sposób jej traktowania, wykonywania i przeżywania. I wreszcie praca daje człowiekowi możliwość kontaktu ze społeczeństwem, działania na rzecz jego rozwoju i dobrobytu, poczucia bycia potrzebnym innym w rozumieniu służby drugiemu człowiekowi.

Nie można mieć więc wątpliwości, że praca człowieka jest kluczowa dla jego wszechstronnego rozwoju oraz rozwoju społeczeństwa. Jednak człowiek i jego praca mogą być wykorzystywani w taki sposób, że będzie ona prowadzić do destrukcji jego osobowości i poczucia niesprawiedliwości, a więc nie przyniesie tych dobrych owoców, o których wspomniano 
wyżej. Celem niniejszego opracowania jest przedstawienie w skrócie problematyki godności pracy człowieka zawartej w encyklice Jana Pawła II Centesimus annus, również w odniesieniu do rzeczywistości społeczno-ekonomicznej po 25 latach od jej ogłoszenia.

\section{Praca człowieka i jej godność}

Refleksję nad rolą i sensem pracy podejmował i ciągle podejmuje Kościół katolicki. We wstępie encykliki Laborem exercens papież Jan Paweł II mówi, że człowiek „stworzony [...] na obraz i podobieństwo Boga Samego wśród widzialnego wszechświata, ustanowiony, aby ziemię czynić sobie poddaną, jest człowiek przez to samo od początku powołany do pracy. [...] Praca wyróżnia go wśród reszty stworzeń [...] tak więc praca nosi na sobie szczególne znamię człowieka i człowieczeństwa, znamię osoby działającej we wspólnocie osób [...]”'. Zarówno encyklika Laborem excrcens, jak i encyklika Centesimus annus odnoszą się do encykliki Rerum novarum, będąc przypomnieniem i uaktualnieniem jakże ważnych zagadnień odnośnie do kwestii robotniczych, kwestii pracy ludzkiej i jej miejsca w zmieniającej się wówczas koncepcji społeczeństwa, państwa i władzy. Z tego też względu problematyka pracy i jej znaczenia zawarta w encyklice Rerum novarum siłą rzeczy w dużej części została przypomniana w encyklice Centesimus annus, a jednocześnie papież Jan Paweł II wskazał na „rzeczy nowe”, wśród których żył Kościół i świat w czasach ogłoszenia tej encykliki.

Papież Jan Paweł II, pokazując znamienne rysy encykliki Rerum novarum, wspomniał, że Leon XIII naświetlił konflikt między kapitałem a pracą, potwierdzając jednocześnie prawa robotników. Kluczowym pojęciem stała się godność robotnika, a więc i godność pracy. Praca ma charakter osobowy i wchodzi w zakres powołania każdego człowieka. W pracy człowiek wyraża się i realizuje. Praca ma również wymiar społeczny, będąc związaną zarówno z rodziną, jak i dobrem wspólnym ${ }^{2}$. $\mathrm{Z}$ tego względu, że praca jest tak ważna dla człowieka i społeczeństwa, państwo nie może uchylać się od stosowania regulacji w relacjach gospodarczych, których celem jest stworzenie podstawowych warunków

1 LE, Wstęp.

${ }^{2}$ Por. ca 6. 
dla zaistnienia pewnej równości pomiędzy stronami rynku pracy tak, aby przywrócić pracy jej godność jako wolnej działalności człowieka³. Przedmiotem tych regulacji powinny być: obrona pracownika przed widmem bezrobocia, odpowiedni poziom zarobków, eliminacja wyzysku, zagwarantowanie „ludzkiego” czasu pracy, prawo do wyrażenia własnej osobowości w miejscu pracy przy zagwarantowaniu nienaruszalności wolności sumienia pracownika ${ }^{4}$.

Koniec xx wieku przyniósł upadek wielu dyktatorskich rządów ucisku. W szczególności trzeba podkreślić zmiany, które zaszły w systemach politycznych i gospodarczych krajów Europy Środkowo-Wschodniej. Papież Jan Paweł II wskazał, że decydującym czynnikiem inicjującym owe zmiany było pogwałcenie praw pracy ${ }^{5}$ oraz niesprawność systemu gospodarczego wynikająca z pogwałcenia praw człowieka do inicjatywy, do własności i do wolności w dziedzinie ekonomicznej ${ }^{6}$, co prowadziło do coraz większej luki rozwojowej między państwami socjalistycznymi a uprzemysłowionymi państwami kapitalistycznymi. W tych drugich dostrzeżono znaczenie własności wiedzy, techniki i umiejętności dla kształtowania się bogactwa krajów. W tym kontekście Jan Paweł II wskazuje na rolę zdyscyplinowanej i kreatywnej pracy oraz rolę zdolności do inicjatywy i przedsiębiorczości w kształtowaniu bogactwa społeczeństwa ${ }^{7}$.

Podsumowując nauczanie dotyczące pracy, papież stwierdza, że poprzez swoją pracę człowiek angażuje się nie tylko dla samego siebie, ale także dla drugich i z drugimi, że pracuje nie tylko dla zaspokojenia potrzeb swojej rodziny, ale również dla wspólnoty, narodu i całej ludzkości. W tym kontekście Jan Paweł II przestrzega przed każdego rodzaju wyzyskiem pracowników płynącym z niewłaściwego wykorzystania własności środków produkcji. Papież podkreśla, że obowiązek zarabiania na chleb jest równocześnie prawem człowieka do zarobkowania, a więc usprawiedliwione etycznie są te środki polityki gospodarczej, które prowadzą do uzyskania możliwości pracy i ludzkiego rozwoju dla wszystkich ${ }^{8}$.

\footnotetext{
Por. CA 15.

4 Por. tamże.

5 Por. CA 23.

6 Por. CA 24.

Por. CA 32.

8 Por. CA 43.
} 


\section{Godziwe wynagrodzenie za pracę}

Praca człowieka związana jest z prawem do korzystania z jej owoców ${ }^{9}$. Jednym z najważniejszych jest płaca lub inaczej - wynagrodzenie za pracę $e^{10}$. Powstaje zasadnicze pytanie, jak wysokie powinno być to wynagrodzenie. Aby na nie odpowiedzieć, należy przywołać jedną z podstawowych funkcji wynagrodzenia, jaką jest funkcja alimentarna (alimentacyjna, socjalna $)^{11}$. Wiąże się ona z możliwością zaspokojenia przez pracownika i jego rodzinę podstawowych potrzeb, zwłaszcza gdy płaca jest jedynym źródłem ich utrzymania. W związku z tak ważną rolą płacy powinna być ona na takim poziomie, aby pozwalała zaspokoić potrzeby pracownika i jego rodziny ${ }^{12}$. $Z$ tego też względu określa się taką płacę jako rodzinną. $Z$ drugiej strony płaca jest ceną za pracę, którą nabywa pracodawca. Przekłada się to na traktowanie jej jako kosztu działalności gospodarczej, co z kolei często wiąże się z działaniem zmierzającym do minimalizowania skali ponoszonych kosztów. Dochodzi więc do starcia się dwóch kategorii: oczekiwania co najmniej takiej płacy, którą dany pracownik mógłby nazwać godziwą, z oczekiwaniem i działaniem pracodawcy skierowanym na co najmniej racjonalizowanie poziomu i struktury ponoszonych kosztów, a więc i funduszu płac. W zależności od siły rynkowej pracowników i pracodawców oraz sytuacji na rynku pracy łatwiej lub trudniej jest pracownikom wynegocjować satysfakcjonujące ich poziomy wynagrodzeń. Zdarza się więc, że pracodawcy w określonej sytuacji społeczno-gospodarczej nie respektują funkcji alimentarnej wynagrodzenia, oferując taki poziom płac swoim pracownikom, który nie gwarantuje zaspokojenia potrzeb pracownika i jego rodziny i który często można uznać za niegodziwy, a wręcz niesprawiedliwy. Trudnością w ocenie poziomu wynagrodzeń jest to, że mogą one mieć wymiar materialny (związany

\footnotetext{
${ }^{9}$ Szerzej na temat nauczania Kościoła odnośnie do pracy i płacy zob. A. Zwoliński, Praca i płaca jako temat nauczania Kościoła, „Studia Socialia Cracoviensia” 5 (2013), nr 1(8), s. 31-49.

${ }^{10}$ Od strony ekonomicznej te dwa pojęcia są najczęściej utożsamiane, chociaż w ujęciu innych nauk, np. socjologii, mogą być rozróżniane. W niniejszym opracowaniu pojęcia te są używane zamiennie.

${ }^{11}$ W literaturze przedmiotu oprócz wspomnianej alimentarnej funkcji płac wymienia się jeszcze funkcję dochodową, kosztową, społeczną i motywacyjną. Zob. M. W. Kopertyński, Motywacje pracowników. Teoria i praktyka, Warszawa 2009, s. 104-106.

${ }^{12}$ Por. K. Łapiński, Godziwe wynagrodzenie za pracę, „Monitor Prawa Pracy” 12 (2011).
} 
bezpośrednio z możliwościami zaspokojenia potrzeb) i wymiar niematerialny (związany z pozycją danej osoby, uznaniem, możliwościami rozwoju czy chociażby lepszymi fizycznymi warunkami pracy). Oczywiste jest to, że nie ma prostego przełożenia owego wymiaru niematerialnego na materialny, co może w jakimś zakresie powodować niedoszacowanie poziomu korzyści uzyskiwanych przez pracownika, gdy mierzymy je jedynie wartościowo.

W kontekst powyższych rozważań wpisuje się problematyka godziwego wynagrodzenia za pracę. Rozpatruje się je w dwóch wymiarach: ogólnym i indywidualnym ${ }^{13}$. Pierwsze ujęcie odnosi się do ustalenia takiego poziomu wynagrodzenia, które powinno zaspokoić bieżące podstawowe potrzeby pracownika i jego rodziny. Jednak wynagrodzenie to nie może być oderwane od efektów pracy danego (indywidualnego) pracownika, co wyraża się w indywidualnym spojrzeniu na poziom płacy godziwej. W związku z uwagami przedstawionymi powyżej, na temat skłonności pracodawców do redukcji kosztów, w tym płac, wydaje się uzasadnione zaangażowanie państwa w ochronę pracowników w tym obszarze. Znalazło to odbicie w zasadzie wyrażonej w art. 13 KP, w myśl której pracownik ma prawo do godziwego wynagrodzenia za pracę. W wielu państwach (również w Polsce) jest ono realizowane poprzez odpowiednią politykę państwa w dziedzinie płac, w tym poprzez ustalenie minimalnego wynagrodzenia za pracę.

Prawo do godziwego wynagrodzenia zostało zawarte w wielu dokumentach międzynarodowych ${ }^{14}$. Należy wskazać przede wszystkim na Powszechną Deklarację Praw Człowieka, która w art. 32, ust. 3 mówi, że „każdy pracujący ma prawo do odpowiedniego i zadowalającego wynagrodzenia, zapewniającego jemu i jego rodzinie egzystencję odpowiadającą godności ludzkiej i uzupełnianego w razie potrzeby innymi środkami pomocy społecznej"15. W art. 7 Międzynarodowego Paktu Praw Gospodarczych, Społecznych i Kulturalnych uznaje się prawo każdego do wynagrodzenia zapewniającego wszystkim pracującym jako minimum

\footnotetext{
${ }_{13}$ Por. tamże.

${ }^{14}$ Por. K. Obrębski, Prawo pracowników do godziwego wynagrodzenia, http://prawodlakazdego.pl/artykuly/prawo-pracowników-do-godziwego-wynagrodzenia (5.02.2016).

${ }_{15}$ Powszechna Deklaracja Praw Człowieka, http://www.unesco.pl/fileadmin/user upload/pdf/Powszechna_Deklaracja_Praw_Czlowieka.pdf (5.02.2016).
} 
m.in. godziwy zarobek i równe wynagrodzenie za pracę o równej wartości ${ }^{16}$. Podobne zapisy znaleźć można w Europejskiej Karcie Społecznej z 1961 roku, w której zapisano m.in., że umawiające się strony zobowiązują się uznać prawo pracowników do takiego wynagrodzenia, które zapewni im i ich rodzinom godziwy poziom życia ${ }^{17}$.

Powstaje pytanie, jak ustalić ów godziwy poziom wynagrodzenia. Opierając się na zapisach Europejskiej Karty Społecznej, komitet niezależnych ekspertów ustalił w 1966 roku, że godziwa płaca stanowić powinna 2/3 przeciętnej płacy danego kraju. Obecnie uznaje się poziom godziwej płacy jako 60\% przeciętnej płacy. Międzynarodowa Organizacja Pracy wiąże natomiast godziwe wynagrodzenie z płacą minimalną, mówiąc, że płaca ta nie powinna być mniejsza niż $50 \%$ przeciętnego wynagrodzenia w danym kraju. Z kolei Organizacja Współpracy Gospodarczej i Rozwoju (oECD) łączy poziom płacy minimalnej z poziomem РКв na mieszkańca danego kraju, przyjmując, że płaca ta powinna stanowić $66 \%$ РКв per capita ${ }^{18}$. Z pewnością powyższe rozwiązania problemu ustalenia godziwego wynagrodzenia mają charakter uproszczony. Wynika to przede wszystkim z braku jednej powszechnie obowiązującej definicji godziwego wynagrodzenia, która pozwalałaby w miarę jednoznacznie wyznaczyć jego poziom. Zaprezentowane ujęcie płacy godziwej odnosi się do jej ogólnego wymiaru, zakładając, że dany (indywidualny) pracownik wykonuje swoje obowiązki w sposób rzetelny, zgodnie z wymaganiami pracodawcy.

Społeczna nauka Kościoła kładzie główny nacisk na ogólny wymiar płacy godziwej, nie pomijając jednocześnie jej wymiaru indywidualnego. Jan Paweł II, przywołując nauczanie Leona XIII z encykliki Rerum novarum, mówi o słusznej płacy będącej prawem robotnika jako osoby. O tej płacy nie może decydować „wolna umowa” stron, która zwalnia pracodawcę po wypłaceniu ustalonej płacy z jakiejkolwiek refleksji nad sytuacją życiową pracowników ${ }^{19}$. Papież wyraźnie mówi, że „płaca musi

\footnotetext{
${ }^{16}$ Por. Międzynarodowy Pakt Praw Gospodarczych, Społecznych i Kulturalnych, http:// isap.sejm.gov.pl/DetailsServlet?id=WDU19770380169 (5.02.2016).

${ }_{17}$ Por. Europejska Karta Społeczna, preambuła, cz. 1, pkt 4, http://isap.sejm.gov.pl/DetailsServlet?id=wDU19990080067 (5.02.2016).

${ }_{18}$ Por. K. Belczyk, Mit godziwego wynagrodzenia, http://wynagrodzenia.pl/artykul.php/ wpis.2548 (5.02.2016).

19 Por. CA 8.
} 
wystarczyć robotnikowi na utrzymanie siebie i rodziny"20, a oczywistym gwałtem jest wymuszanie przez pracodawców niekorzystnych warunków pracy dla pracownika obawiającego się jeszcze gorszej sytuacji swojej i swojej rodziny, gdyby tej pracy nie podjął. Z troską Jan Paweł II konkluduje, że także dzisiaj (1991 rok) spotkać można takie umowy o pracę, które łamią najbardziej elementarne zasady sprawiedliwości, w tym prawo do słusznego wynagrodzenia ${ }^{21}$. Praca nie jest bowiem wyłącznie towarem lub usługą $a^{22}$, które można swobodnie kupować i sprzedawać niezależnie od minimum życiowego niezbędnego do utrzymania danego pracownika i jego bliskich. W tym kontekście płaca powinna być wystarczająca do utrzymania rodziny ${ }^{23}$, a społeczeństwo i państwo powinno gwarantować taki poziom zarobków, by to umożliwiły, a nawet pozwoliły zgromadzić pewne oszczędności ${ }^{24}$. Zwięzłe podsumowanie nauczania Kościoła odnośnie do płacy znajdujemy w Katechizmie Kościoła katolickiego, gdzie zapisano, że „aby ustalić słuszne wynagrodzenie, należy uwzględnić jednocześnie potrzeby i wkład pracy każdego. Należy tak wynagradzać pracę, aby dawała człowiekowi środki na zapewnienie sobie i rodzinie godnego stanu materialnego, społecznego, kulturalnego i duchowego stosownie do wykonywanych przez niego zajęć, wydajności pracy, a także zależnie od warunków zakładu pracy i z uwzględnieniem dobra wspólnego. Porozumienie stron nie wystarczy do moralnego usprawiedliwienia wysokości wynagrodzenia"25.

\section{Płaca minimalna a płaca godziwa}

W Polsce płaca minimalna jako kategoria ekonomiczna funkcjonuje od $1956 \mathrm{roku}^{26}$. Chociaż sposób jej wyznaczania w tak długim okresie ulegał zmianom, to zawsze wyrażała ona pewien minimalny gwarantowany przez państwo poziom wynagrodzenia za pracę. Od 1 stycznia 2003 roku

\footnotetext{
${ }^{20}$ Tamże.

${ }^{21}$ Por. tamże.

${ }^{22}$ Por. CA 4, 34.

${ }^{23}$ Por. CA 34.

${ }^{24}$ Por. CA 15.

${ }^{25} \mathrm{KKK}, 2434$.

${ }^{26}$ Por. Minimalne wynagrodzenie za prace, http://www.mpips.gov.pl/prawo-pracy/wynagrodzenia (5.02.2016).
} 
weszła w życie w Polsce Ustawa o minimalnym wynagrodzeniu za pracę, zgodnie z którą poziom tego wynagrodzenia ustala właśnie akt prawny. W tym czasie minimalna płaca wynosiła 800 zł. Sposób wyznaczania poziomu minimalnego wynagrodzenia jest oparty o zmiany wskaźnika cen towarów i usług konsumpcyjnych ogółem oraz prognozowany poziom wskaźnika realnego przyrostu РКв. Trzeba również dodać, że wysokość płacy minimalnej jest wynikiem negocjacji i ustaleń na forum Trójstronnej Komisji do spraw Społeczno-Gospodarczych ${ }^{27}$. W kolejnych latach poziom płacy minimalnej systematycznie wzrastał, tak że w roku 2015 wyniosła ona $1750 \mathrm{zł}$.

W większości państw europejskich stosowana jest kategoria płacy minimalnej, chociaż sposób jej wyznaczania i zastosowania nie jest jednolity. Z tego też względu można by uznać, że bezpośrednie porównania jej poziomu są utrudnione. Nic nie stoi jednak na przeszkodzie, aby zestawić ze sobą poziom gwarancji państwowych co do wynagrodzenia z poszczególnych krajów. Nie chodzi bowiem o to, jaki poziom minimalnej płacy wyznaczy nam taka czy inna metoda, ale o to, jaki poziom płac gwarantuje dane państwo i jak się on ma do poziomu godziwego wynagrodzenia. Tak naprawdę metoda wyznaczania minimalnej płacy jest wtórna w kontekście jej roli jako gwaranta określonych (minimalnych) warunków życia pracownika i jego rodziny.

W tabelach 1 i 2 zestawiono wartości przeciętnej płacy miesięcznej, płacy minimalnej, 60\% udziału płacy przeciętnej, udziału płacy minimalnej w płacy godziwej oraz w płacy przeciętnej dla wybranych państw europejskich. Dane na temat płac w tabeli 1 wyrażone są w euro natomiast $\mathrm{w}$ tabeli $2-\mathrm{w}$ specjalnych jednostkach przeliczeniowych (PPS), uwzględniających siłę nabywczą pieniądza w danym kraju.

Przeciętne płace oraz płace minimalne różnią się zasadniczo w wybranych krajach. Warto zwrócić uwagę, że to zróżnicowanie jest większe w przypadku płac wyrażonych w euro niż w umownych jednostkach PPs. Jak już wspomniano, te drugie biorą pod uwagę koszty życia (funkcjonowania) w danym społeczeństwie, co powoduje, że poziom płac wyrażonych w PPS w Luksemburgu spada, a w Bułgarii rośnie w odniesieniu do poziomu płac ujętych w euro. Zgodnie z zapisami Europejskiej Karty Społecznej godziwy poziom płac powinien wynosić co najmniej

${ }^{27}$ W 2015 r. Komisja ta została zastąpiona przez Radę Dialogu Społecznego. 
$60 \%$ przeciętnego wynagrodzenia. Na tej podstawie w kolejnej kolumnie tabel 1 i 2 przedstawiono wyniki odpowiednich obliczeń. W dwóch ostatnich kolumnach zestawiono udział płacy minimalnej w płacy godziwej i płacy minimalnej w przeciętnej ${ }^{28}$. Ten drugi udział odnosi się do koncepcji godziwego wynagrodzenia według MOP (wynagrodzenie godziwe to taka płaca minimalna, która stanowi 50\% przeciętnego wynagrodzenia). W obydwu przypadkach Polska jest najbliżej osiągnięcia stanu, kiedy płacę minimalną można by uznać za godziwą, natomiast najdalej od takiej konkluzji są Czechy i Hiszpania.

Tabela 1. Przeciętna płaca miesięczna i płaca minimalna i ich relacje w wybranych państwach europejskich (płace w euro)

\begin{tabular}{l|c|c|c|c|c} 
Państwo & $\begin{array}{c}\text { Przeciętna } \\
\text { płaca } \\
\text { miesięczna }\end{array}$ & $\begin{array}{c}\text { Płaca } \\
\text { minimalna }\end{array}$ & $\begin{array}{c}60 \% \text { płacy } \\
\text { przeciętnej } \\
\text { - płaca } \\
\text { godziwa }\end{array}$ & $\begin{array}{c}\text { Udział płacy } \\
\text { minimalnej } \\
\text { w godziwej } \\
(\mathrm{w} \%)\end{array}$ & $\begin{array}{c}\text { Udział płacy } \\
\text { minimalnej } \\
\text { w przeciętnej } \\
(\mathrm{w} \%)\end{array}$ \\
\hline Bułgaria & 423,36 & 173,84 & 254,01 & 68,44 & 41,06 \\
\hline Czechy & 944,47 & 309,62 & 566,68 & 54,64 & 32,78 \\
\hline Grecja & 1680,66 & 683,76 & 1008,40 & 67,81 & 40,68 \\
\hline Hiszpania & 2180,15 & 752,85 & 1308,09 & 57,55 & 34,53 \\
\hline Francja & 3118,95 & 1445,38 & 1871,37 & 77,24 & 46,34 \\
\hline Luksemburg & 4546,70 & 1921,03 & 2728,02 & 70,42 & 42,25 \\
\hline Polska & 843,63 & 404,16 & 506,18 & 79,85 & 47,91 \\
\hline Rumunia & 518,49 & 205,34 & 311,09 & 66,01 & 39,60
\end{tabular}

Źródło: opracowanie własne na podstawie danych z Eurostatu.

${ }^{28}$ Wyniki w dwóch ostatnich kolumnach obydwu tabel $\mathrm{z}$ zasady powinny być takie same - zarówno w przypadku płacy przeciętnej, jak i minimalnej powinien być stosowany ten sam przelicznik dla uzyskania jednostek PPs. Warto jednak zauważyć, że płace przeciętne wyznaczono na podstawie danych $\mathrm{z}$ całego roku, a płaca minimalna jest jedną wartością niezmienną $\mathrm{w}$ danym okresie. Jeśli w przypadku płac otrzymywanych przeliczano je przy wykorzystaniu zmienionych w ciągu danego roku przeliczników, może to spowodować niewielkie różnice w otrzymanych udziałach. 
Tabela 2. Przeciętna płaca miesięczna i płaca minimalna i ich relacje w wybranych państwach europejskich (płace w PPs)

\begin{tabular}{l|c|c|c|c|c} 
Państwo & $\begin{array}{c}\text { Przeciętna } \\
\text { płaca } \\
\text { miesięczna }\end{array}$ & $\begin{array}{c}\text { Płaca } \\
\text { minimalna }\end{array}$ & $\begin{array}{c}60 \% \text { płacy } \\
\text { przeciętnej }- \\
\text { płaca } \\
\text { godziwa }\end{array}$ & $\begin{array}{c}\text { Udział płacy } \\
\text { minimalnej } \\
\text { w godziwej } \\
(\mathrm{w} \%)\end{array}$ & $\begin{array}{c}\text { Udział płacy } \\
\text { minimalnej } \\
\text { w przeciętnej } \\
(\mathrm{w} \%)\end{array}$ \\
\hline Bułgaria & 874,52 & 363,18 & 524,71 & 69,22 & 41,53 \\
\hline Czechy & 1471,70 & 484,57 & 883,02 & 54,88 & 32,93 \\
\hline Grecja & 1950,79 & 800,33 & 1170,47 & 68,38 & 41,03 \\
\hline Hiszpania & 2351,71 & 815,54 & 1411,02 & 57,80 & 34,68 \\
\hline Francja & 2893,73 & 1341,01 & 1736,24 & 77,24 & 46,34 \\
\hline Luksemburg & 3785,35 & 1595,05 & 2271,21 & 70,23 & 42,14 \\
\hline Polska & 1510,68 & 719,05 & 906,41 & 79,33 & 47,60 \\
\hline Rumunia & 954,46 & 381,16 & 572,67 & 66,56 & 39,93
\end{tabular}

Źródło: opracowanie własne na podstawie danych z Eurostatu.

\section{Podsumowanie}

Problematyka nierówności ekonomicznych i społecznych, sprawiedliwości dystrybutywnej, dobrobytu i ubóstwa oraz dyskryminacji jest stale obecna w życiu społecznym, a więc i w dyskursie naukowym. Nie możemy się więc dziwić, że katolicka nauka społeczna podejmuje tę problematykę również poprzez oficjalne nauczanie papieży. Widząc niesprawiedliwość stosunków społecznych, podejmują oni refleksję nad ich przyczynami, apelując jednocześnie o taką organizację życia społecznego, która zachowywałaby godność każdego człowieka. W tym duchu napisana została encyklika Jana Pawła II Centesimus annus, która potwierdza ciągłą aktualność głównych problemów społecznych podniesionych przez papieża Leona XIII w encyklice Rerum novarum, chociaż skala ich występowania $\mathrm{z}$ pewnością jest inna. Nie jest już bowiem dominującym model kształtowania stosunków społeczno-ekonomicznych zwany „dzikim kapitalizmem" - w krajach rozwiniętych państwo stara się chronić prawa pracowników i roztaczać opiekę nad bezrobotnymi i słabszymi. Pomimo tego cały czas jest wielu takich pracodawców, którzy wykorzystując luki w prawie lub interpretując je niezgodnie z jego „duchem”, równocześnie wykorzystują człowieka i jego pracę. Dobrym przykładem w Polsce są tzw. 
„umowy śmieciowe”, które stosuje się nierzadko nawet w sytuacji, kiedy stosunek pracy jest typowy dla zatrudnienia w ramach umowy o pracę, ograniczając w ten sposób prawa pracowników. Innym przykładem jest przymuszanie pracownika do pracy w tzw. „szarej strefie”, dyskryminowanie poszczególnych grup pracowniczych, praca w nadgodzinach w ramach tzw. pełnej dyspozycyjności pracownika oraz zaniżanie lub wręcz niewypłacanie należnego wynagrodzenia. To wszystko wskazuje na aktualność wołania Jana Pawła II o godność człowieka i jego pracy, które zostało zawarte w omawianej w tym opracowaniu encyklice, chociaż - jak pokazuje ostatnie 25 lat - sytuacja pracowników na rynku pracy w Polsce poprawia się zarówno pod względem możliwości zatrudnienia, jego ochrony, jak i poziomu uzyskiwanego wynagrodzenia.

\section{Bibliografia}

Belczyk K., Mit godziwego wynagrodzenia, http://wynagrodzenia.pl/artykul. php/wpis.2548 (5.02.2016).

Jan Paweł II, Encyklika Centesimus annus, przedruk: Libreria Editrice Vaticana, Włocławek 1991.

Jan Paweł II, Encyklika Laborem exercens, Wydawnictwo Ośrodka Dokumentacji i Studiów Społecznych, Warszawa 1982.

Katechizm Kościoła katolickiego, Pallottinum, Poznań 2002.

Kopertyński M. W., Motywacje pracowników. Teoria i praktyka, Warszawa 2009. Łapiński K., Godziwe wynagrodzenie za pracę, „Monitor Prawa Pracy” 12, http:// czasopisma.beck.pl/monitor-prawa-pracy/, (5.02.2016)

Minimalne wynagrodzenie za prace, http://www.mpips.gov.pl/prawo-pracy/wynagrodzenia (5.02.2016).

Obrębski K., Prawo pracowników do godziwego wynagrodzenia, http:/prawodlakazdego.pl/artykuly/prawo-pracowników-do-godziwego-wynagrodzenia (5.02.2016).

Zwoliński A., Praca i płaca jako temat nauczania Kościoła, „Studia Socialia Cracoviensia" 5 (2013), $\mathrm{nr}$ 1(8), s. 31-49.

\section{Abstrakt}

Artykuł skupia się na problematyce pracy człowieka i jej godności, poruszonej w encyklice Jana Pawła II Centesimus annus, w kontekście rzeczywistości 
społeczno-gospodarczej po 25 latach od ogłoszenia tej encykliki. Szczególną uwagę zwrócono na problem godziwego wynagrodzenia za pracę, przedstawiając również skrótowo dane liczbowe odnoszące się do płac w wybranych krajach europejskich.

The human work and its decent remuneration in the light of the encyclical Centesimus annus

\begin{abstract}
The article focuses on the problems of human work and its dignity raised in the encyclical of John Paul II Centesimus annus in the context of socio-economic reality after 25 years of the publication of the encyclical. Particular attention is paid to the problem of equitable remuneration for the work, there are also briefly shown numerical data related to wages in selected European countries.
\end{abstract}

